\title{
Morphological alterations in Neotropical Ceratopogonidae (Diptera)
}

\author{
Maria L. Felippe-Bauer \& Cristiane S. Silva
}

Departamento de Entomologia, Instituto Oswaldo Cruz-Fiocruz, Av. Brasil 4365, Manguinhos, 21040-900 Rio de Janeiro, Rio de Janeiro, Brasil. E-mail: mlfbauer@ioc.fiocruz.br

\begin{abstract}
Morphological alterations in six different species of females Culicoides Latreille, 1809 and one of Monohelea Kieffer, 1917 from Brazil, Mexico, Panama and Peru are described. The correlation of the morphological changes with the taxonomy and behavior of the species is discussed.

KEY WORDS. Aberrations; Culicoides; midges; Monohelea.
\end{abstract}

\begin{abstract}
RESUMO. Alterações morfológicas em Ceratopogonidae (Diptera) Neotropicais. São descritas as alterações morfológicas em fêmeas de seis espécies de Culicoides Latreille, 1809 e uma de Monohelea Kieffer, 1917 provenientes do Brasil, México, Panamá e Peru. É discutida a correlação das alterações morfológicas com a taxonomia e as atividades das espécies.
\end{abstract}

PALAVRAS CHAVE. Anomalias; ceratopogonídeos; Culicoides; Monohelea.

Anomalies have been cited in both sexes in all well known insects' orders such as Coleoptera, Hymenoptera, Lepidoptera, Orthoptera and Diptera (Cockayne 1915). Several authors have demonstrated association of abnormal insect development in those infected by nematodes. This parasitism normally leads to host death upon emergence (Welch 1965). The survivors can present intersexual characters. In intersex specimens of Ceratopogonidae some authors reported morphological alterations in antennae, mouthparts, wings or genitalia. In Culicoides Latreille, these abnormalities have been reported mainly in neartic and paleartic species (e.g. Callot \& Kremer 1963, Smith \& Perry 1967, McKeever et al. 1997) and morphological alterations unrelated to intersexuality and/or parasitism have been poorly cited. Only KoRneva (1965) described some morphological changes unrelated to intersexuality in three Russian species of Culicoides such as differences in eyes separation, number of interocular hairs, and number of spermathecae. Aberrations related to the quantity or the aspect of structures with taxonomic importance may result in erroneous interpretations and therefore their descriptions can help in the correct species analysis. Furthermore, anomalies in structures with specific functions can affect the life activities of the specimens and need to be investigated.

The objective of this paper is to describe the abnormal structures found in Neotropical Ceratopogonidae taking into consideration the taxonomy and behavior of the species.

\section{MATERIAL AND METHODS}

The material was mounted on microscope slides using the technique described by Wirth \& MARSTON (1968) and the anomalous structures were photographed by a microscope digi- tal camera. Specimens are deposited at the Entomological Collection of Instituto Oswaldo Cruz, Rio de Janeiro, Brazil, except for Culicoides maruim Lutz, 1913 and C. foxi Ortiz, 1950, which were send back to the Institutions that loaned them.

\section{RESULTS}

The anomalies found out in six species of Culicoides Latreille and one of Monohelea Kieffer are described below:

Eyes. Interocular hair absent in Culicoides paraensis (Goeldi, 1905) (Fig. 1), normally present in all species of Culicoides. Specimen examined - BrasIL, Santa Catarina: Jaraguá do Sul, 1 female, 2002, Ulises Sternheim leg., biting human.

Antenna. Right flagellomeres 6 and 7 fused on ventral side (Fig. 2); left flagellomeres 6 and 7 with normal aspect (Fig. 3) in C. peruvianus Felippe-Bauer, 2003. Specimen examined - Peru, Amazonas: Provincia Utcubamba, Distrito Jamalca, Aserradero, 1 female, 19.VIII.2001, Gonzales-Perez leg., biting human.

Left flagellomere 13 atrophied (Fig. 4); right flagellomere 13 with normal length (Fig. 5) in Monohelea maya Felippe-Bauer, Huerta \& Ibáñez-Bernal, 2000. Specimen examined - Mexico, Yucatán: Celestún (Rancho Loma Bonita, Km 15 Carretera Celestún-Kinchild), 1 female, 09.IV.1997, IBS, HJH, MML, MSP leg., malaise trap.

Palpus. Right palpus with additional palpal pit; left palpus with normal number of palpal pit in C. covagarciai Ortiz, 1950 (Fig. 6) and C. foxi. Specimens examined - C. covagarciai, Panama, Chiriqui: Fortuna, 1 female, 23.II.1976, T.H.G. Aitken leg., light trap (photo presented); C. foxi, BrasIL, São Paulo: Vale do Ribeira (Parque Estadual Turístico do Alto Ribeira), 1 female, XI.2000III.2001, AMM, EABG, MBF, LMGA, JRA leg., malaise trap.

Revista Brasileira de Zoologia 23 (3): 593-596, setembro, 2006 

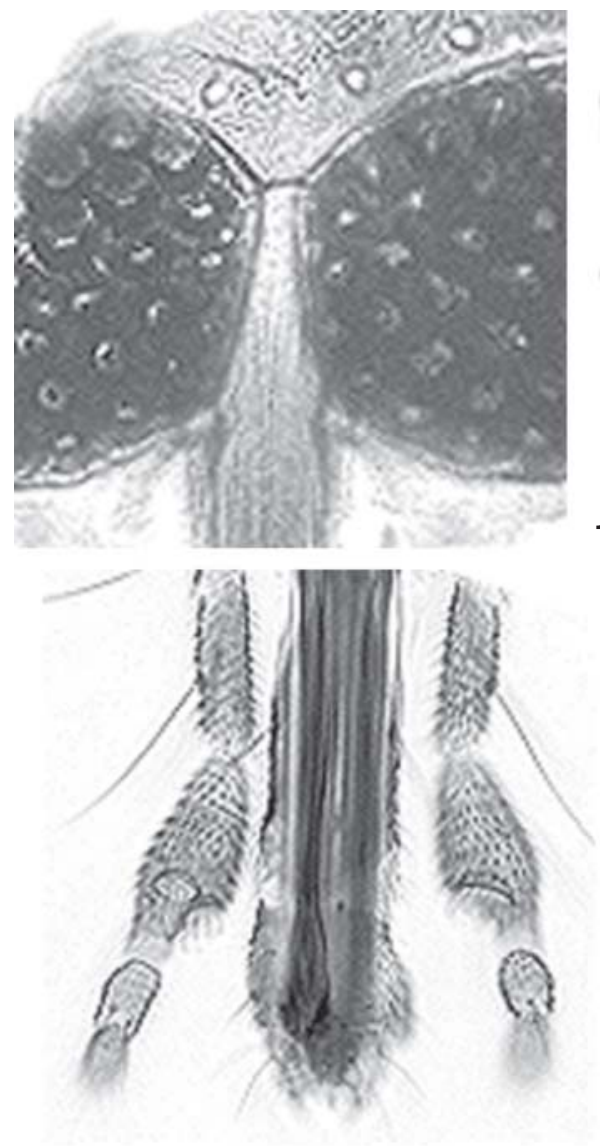

6
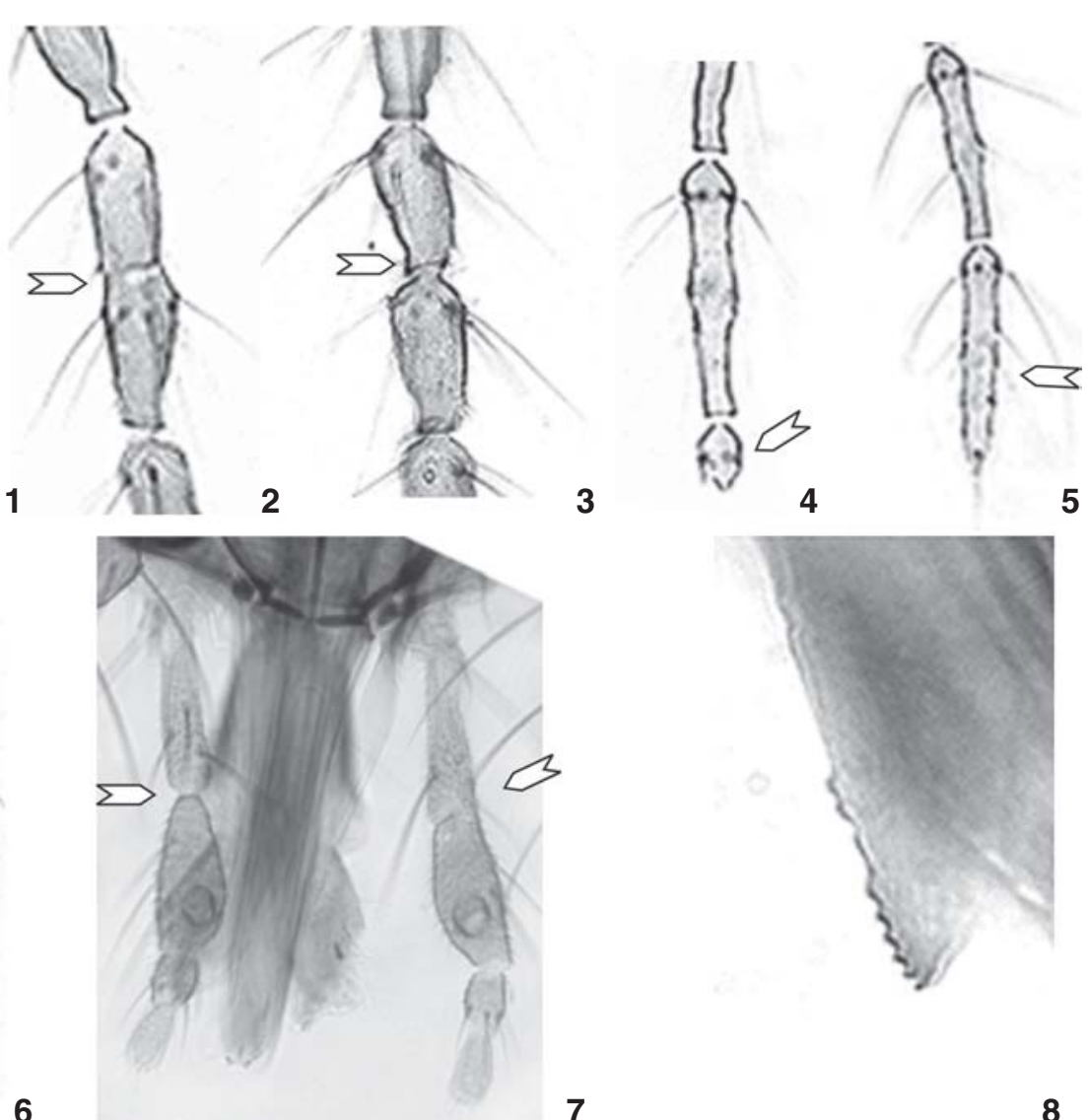

Figures 1-8. (1) Culicoides paraensis, dorsal portion of head capsule, in anterior view, without interocular hair; (2-3) C. peruvianus, right flagellomeres 6 and 7 fused on ventral side (2); left flagellomeres 6 and 7 with normal aspect (3); (4-5) Monohelea maya, left flagellomere 13 atrophied (4); right flagellomere 13 with normal length (5); (6) C. covagarciai, right palpus with additional palpal pit and left palpus with normal aspect; (7) C. peruvianus, left palpal segments 2 and 3 fused and right palpal segments 2 and 3 with normal aspect; (8) C. peruvianus, mandible deformed.

Left palpal segments 2 and 3 fused; right palpal segments 2 and 3 with normal aspect in C. peruvianus (Fig. 7). Specimen examined - Peru, Amazonas: Provincia Utcubamba, Distrito Cajaruro, San Antonio, 1 female, 13.V.2001, Gonzales-Perez leg., biting human.

Mandible. The last 12 distal teeth of left mandible, deformed (Fig. 8) in C. peruvianus. Specimen examined - Peru, Amazonas: Provincia Utcubamba, Distrito Cajaruro, San Antonio, 1 female, Gonzales-Perez leg., biting human.

Wing. Right wing anomalous. Vein $\mathrm{M}_{1}$ bifurcated and pale spots of cell $m_{1}$ duplicated (Fig. 9); left wing with normal aspect (Fig. 10) in C. peruvianus. Specimen examined - Peru, Cajamarca: Provincia San Ignacio, Distrito La Coipa, Payal Bajo, 1 female, 13.II.2002, Abraham G. Cáceres, Eusebio León and Mario Troyes leg., biting human at 17:00 to 20:00 h.

Both wings without subapical pale spot in cell $\mathrm{m}_{1}$ (Fig.
11) and left wing with subapical pale spot of cell $r 5$ subdivided in C. paraensis (Fig. 12). Specimen examined -PERU, Amazonas: Provincia Utcubamba, Distrito Jamalca, Aserradero, 1 female, 10.III.2002, Gonzales-Perez leg., biting human.

Both wings without apical pales spots in cell $\mathrm{r} 5$ in C. paraensis. Specimen examined: BrasiL, Santa Catarina: Jaraguá do Sul, 1 female, 20-27. I.2004, Ulises Sternheim leg., emergence trap.

Tarsus. Left first tarsomere with two basal spines (Fig. 13); right first tarsomere with a common number (1) of basal spines in M. maya (Fig. 14) and C. maruim. Specimens examined - M. maya, Mexico, Yucatán: Celestún (Rancho Loma Bonita, Km 15 Carretera Celestún-Kinchild), 1 female, 09.IV.1997, IBS, HJH, MML, MSP leg., malaise trap (photo presented); C. maruim, Brasil, Pará: São Caetano de Odivelas (Ilha do Rato), 1 female, 26-28.VIII.2000, Rosimeire L. Trindade, José A.N. Pena \& Luiz A.S. Sousa leg., malaise trap. 

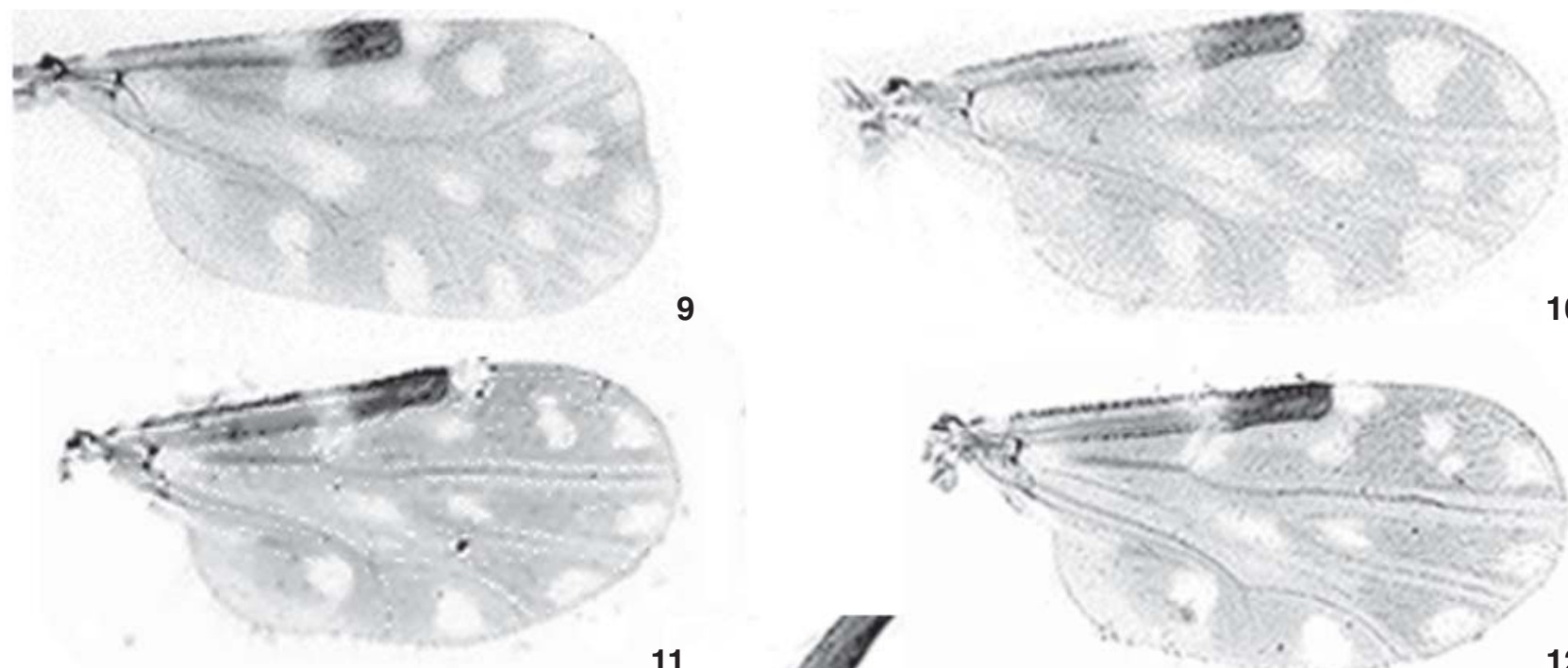

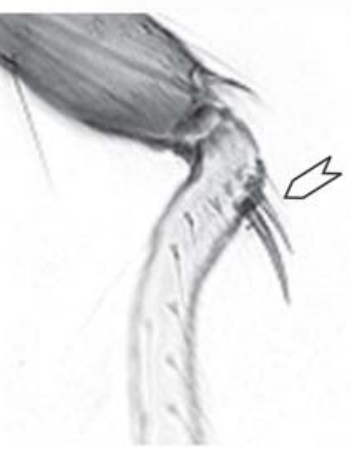

13

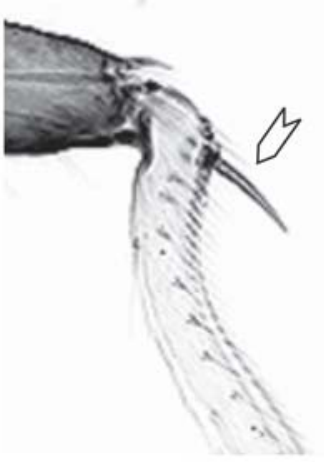

14

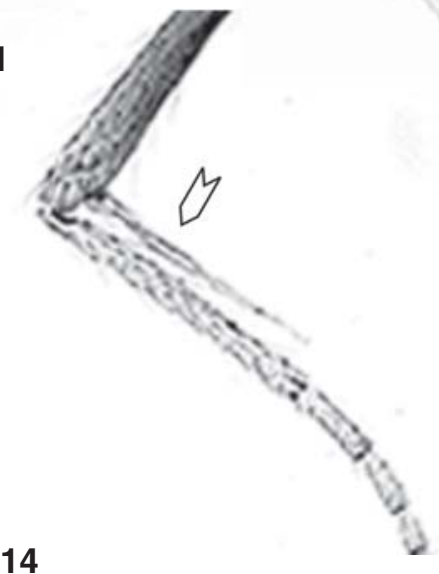

15

Figures 9-16. (9-10) C. peruvianus, anomalous right wing (9); normal left wing (10); (11-12) C. paraensis, right wing without subapical pale spot in cell $\mathrm{m}_{1}(11)$. left wing without subapical pale spot in cell $\mathrm{m}_{1}$ and with subapical pale spot of cell $\mathrm{r} 5$ subdivided (12); (13-14) Monohelea maya, left first tarsomere with two basal spines (13); right first tarsomere with one basal spine (14); (15) C. peruvianus, median leg with an atrophied extra tarsus; (16) Culicoides guttatus, spermathecae in number of three.

Left median leg with an extra tarsus atrophied in $C$. peruvianus (Fig. 15). Specimen examined - Peru, Cajamarca: Provincia San Ignacio, Distrito La Coipa, Payal Bajo, 1 female, 13.II.2002, biting human at 17:00 to 20:00 h.

Spermathecae. Additional spermatheca in C. guttatus (Coquillett, 1904) (Fig. 16). Normally two. Specimen examined - BRasIL, Rio de Janeiro: Campos dos Goytacazes (Cordeiro Moreira), 1 female, 07.III.1990, FEEMA leg., New Jersey trap.

\section{DISCUSSION}

KoRNeva (1965) reported variations in the distance of eyes separation, with or without a superior transverse suture and with one (common number) or two interocular hairs in Culicoides fascipennis (Staeger 1839), C. subfasciipennis Kieffer, 1919 and C. vexans (Staeger, 1839). In our study, one specimen of $C$. paraensis does not display the interocular hair, normally present in all species of Culicoides (see DownEs \& WIRTH 1981, BORKENT 2004).

In some species of Culicoides the number of spermathecae can vary. In C. subfasciipennis and in C. vexans the number varies from two to three (KoRneva 1965). C. guttatus normally present two, but one specimen with three was identified. The number, length and aspect of spermathecae are used in the taxonomy of Culicoides, however the examination of other features is important to determine the species incontestably.

One specimen of $C$. peruvianus has atrophied extra tarsus on the left median leg and a great abnormality on the right wing. Another specimen carries last 12 mandible distal teeth deformed. As these two anomalous specimens were captured feeding on humans, we can conclude that these aberrations, didn't affect the flight activity and feeding habits of the specimens.

Two specimens of $C$. paraensis have anomalies in both

Revista Brasileira de Zoologia 23 (3): 593-596, setembro, 2006 
wings. The number and distribution of pale spots on the wings does not correspond to that described by Wirth \& Felippe-Bauer (1989) and Felippe-Bauer et al. (2003) in their revision of $C$. paraensis group. But the analysis of other characters and the study of other specimens collected in the same locality, prompt us to identify these anomalous specimens as $C$. paraensis.

Sexual anomalies or parasitism has not been found in any of the studied species. Therefore, these morphological alterations are probably due to genetic or morphogenetic malformation.

\section{ACKNOWLEDGEMENTS}

To Abraham G. Cáceres for the opportunity of study the material from Peru. To Rosemeire Lopes da Trindade and Mauro Breviglieri Fonseca for the study of the Brazilian material of Culicoides, respectively, C. maruim and C. foxi.

\section{REFERENCES}

Borkent, A. 2004. The biting midges, Ceratopogonidae (Diptera), p.113-126. In: W.C. Marquardt (Ed.). Biology of Disease Vectors. Burlington, Elsevier Academic Press, $2^{\text {nd }}$ ed., 785p. Callot, J. \& M. Kremer. 1963. Intersexués chez des Culicoides (Diptera: Ceratopogonidae). Annales de Parasitologie, Paris, 38 (1): 113-120.

Cockayne, E.A. 1915. "Gynandromorphism" and kindred problems. With descriptions and figures of some hitherto undescribed examples. Journal of Genetics, Bangalore, 5: 75-131.

Downes, J.A. \& W.W. WirTh. 1981. Ceratopogonidae, p. 393-

Received in 12.VIII.2006; accepted in 09.VI.2006.
421. In: J.F. McAlpine (Ed.). Manual of Neartic Diptera. Quebec, Research Branch Agriculture Canada, Monograph 27, vol. 1, VI+672p.

Felippe-Bauer, M.L.; A.G. Cáceres; C.S. Silva; W. Walderrama-Bazan \& A.G. Perez. 2003. Two new Culicoides of the paraensis Species group (Diptera: Ceratopogonidae) from the Amazonian Region of Peru. Memórias do Instituto Oswaldo Cruz, Rio de Janeiro, 98 (8): 1051-1058.

KoRNEVA, K.T. 1965. Variability of some morphological characters of Heleids, Culicoides fascipennis Staeg., C. subfascipennis Kieff. and C. vexans Staeg. Zoologichesky Zhurnal, Moscow, 44: 620-622.

McKeever, S.; D.S. Brickle \& D.V. Hogan. 1997. Mouthparts, antennae and genitalia of Intersex Culicoides stellifer parasitized by mermithid nematodes. Medical and Veterinary Entomology, Oxford, 11: 217-222.

Smith, W.W. \& V.G. Perry. 1967. Intersexes in Culicoides spp. caused by mermithid parasitism in Florida. Journal of Economic Entomology, Maryland, 60 (4): 1025-1027.

Welch, H.E. 1965. Entomophilic nematodes. Annual Review of Entomology, California, 10: 275-302.

Wirth, W.W. \& M.L. Felippe-Bauer. 1989. The Neotropical biting midges related to Culicoides paraensis (Diptera: Ceratopogonidae). Memórias do Instituto Oswaldo Cruz, Rio de Janeiro, 84 (Suppl. 4): 551-565.

Wirth, W.W. \& N. Marston. 1968. A method for mounting small insects on microscope slide in Canada Balsam. Annals of the Entomological Society of America, Maryland, 61: 783784. 